\title{
Analysis of Masonry Infill in Multi Story Structure
}

\author{
Deshmukh Vishwajeet \\ P.G. Student,Department of Applied Mechanics \\ Walchand College of Engineering, Sangli, Maharashtra,India \\ Dr.Shrirang Tande \\ Professor, Department of Applied Mechanics \\ Walchand College of Engineering, Sangli,Maharashtra,India
}

\begin{abstract}
In this paper, the effect of masonry infills on the seismic response of a four-story reinforced concrete frame has been studied. Seismic analysis has been performed using Response Spectra Method for different reinforced concrete (RC) frame building models that include bare frame, in-filled frame without opening and in-filled frame with opening. The results of bare frame, in-filled frame and in-filled frame with opening are discussed and conclusions are made for base shear, Displacement. In modeling the masonry infill panels the Equivalent diagonal Strut method is used and the software ETABS 2015 is used for the analysis of all the frame models.
\end{abstract}

Keywords: Masonry infill, RC frame, Equivalent Diagonal Strut, Response spectra method

\section{INTRODUCTION}

Masonry walls built as infill between reinforced concrete frame, beam and column are usually considered as nonstructural element. Infilled frame structures are used to provide lateral resistance in regions of high seismicity, especially in those places where masonry is still a convenient material, due to economical and traditional reasons. Infill walls act as diagonal struts and increase the stiffness of RC frame building. The increase in the stiffness depends on the wall thickness and number of frame panel with infills. Masonry infills are functioning mostly as partitions and exterior walls. There are two different approaches for designing masonry in-filled concrete frames depending on local construction site. In the first approach, masonry infill is taken as a part of structural system and they are assumed to brace the frame against horizontal loading. In the second approach, the frame is designed to carry the total vertical and horizontal loading. Moreover, masonry infill is uncoupled to avoid load being transferred to them. In earthquake prone regions like India, masonry infill walls are counted as non-structural elements. They are not taken into account at design stage. Generally the lateral deflection of a frame under lateral load is calculated by taking the stiffness of columns and beams into consideration. But the stiffness of infill is never considered in these calculations. The presence of infill increases the stiffness of the frame, which reduces the lateral deflection. Thus the deflections and internal forces for frames with infill are less than for frames with infill. The present code of practice does not include provision of taking into consideration the effect of infill. It can be expected that if the effect of infill is taken into account, the design of resulting structural elements may be significantly different.

\section{METHODOLOGY}

\subsection{Equivalent Diagonal Strut Method:}

The most accepted method for the analysis of in-filled frame structure is Equivalent Diagonal Strut Method in which entire infill is replaced by a single equivalent strut. In this method beams and column are designed as frame members which are having six DOF at every node and brick infill is replaced by a pin jointed diagonal strut. The thickness of a pin jointed diagonal strut is considered to be same as infill and its length is equal to the length of the diagonal between the two compression corners. Width of a strut is calculated by using Smith's formula. 


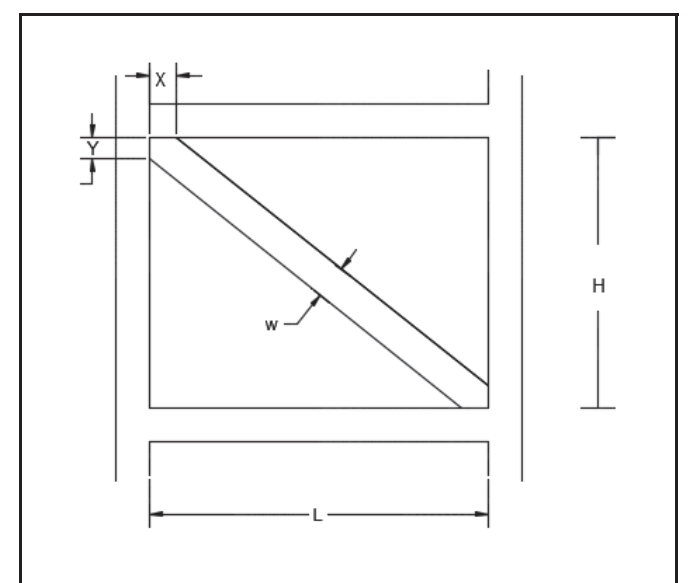

Figure 2.1: Equivalent Diagonal Strut Model

$$
\mathrm{w}=\frac{1}{\mathrm{a}} \sqrt{\mathrm{R}+\gamma^{2}}
$$

Here, the parameter $\mathrm{X}$ and $\mathrm{Y}$ (indicated in Fig) are computed as

Where,

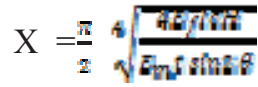

$$
\begin{aligned}
& \mathrm{Y}=\pi \sqrt[4]{\frac{4 \ln _{\ln } \mathrm{B}}{\bar{e}_{\mathrm{n}} \sin 2 \theta}}
\end{aligned}
$$

$\mathrm{W}=$ width of equivalent strut

$\mathrm{E}_{\mathrm{m}}, \mathrm{E}_{\mathrm{f}}=$ Elastic modules of the masonry \& frame materials respectively

$\mathrm{H}=$ height of the infill wall

$\mathrm{L}=$ length of the infill wall

$\mathrm{I}_{\mathrm{c}}=$ moment of inertia of column

$\mathrm{I}_{\mathrm{b}}=$ moment of inertia of beam

$\theta=$ slope of infill diagonal to the horizontal

For the infilled frame with opening diagonal strut width is depend on the strut width reduction factor ( $\left.\rho_{\mathrm{w}}\right)$ and opening area ratio $\left(\alpha_{\mathrm{co}}\right)$. Strut width reduction factor is defined as ratio of reduced strut-width to strut-width corresponding to fully infilled frame, i.e.

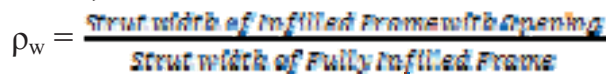

And Opening area ratio $\left(\alpha_{\mathrm{co}}\right)$ is defined as

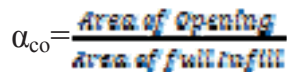

$$
\rho_{\mathrm{w}}=1-2.6 \rho_{\mathrm{w}}
$$

From the above equation we can calculate the strut width of in-filled frame with opening. [1]

\subsection{Response Spectrum Method}

This method is applicable for those structures where modes other than the fundamental one affect significantly the response of the structure. In this method the response of Multi-Degree of freedom (MDOF) system is expressed as the superposition of modal response, each modal response being determined from the spectral analysis of single degree of freedom (SDOF) system, which is then combined to compute the total response. 


\section{PROBLEM FORMULATION}

A 4 story building with 3 meters height for each story, regular in plan is considered. This building is considered to be situated in seismic zone III. The building is modeled using software ETABS 2015. Linear dynamic analysis is carried out and model is studied for comparing lateral displacement, base shear and Time Period. Window Opening is considered in central bay of size $1.22 \mathrm{~m} \mathrm{X} 1.82 \mathrm{~m}$

Table 1 Description of Modeled Buildings

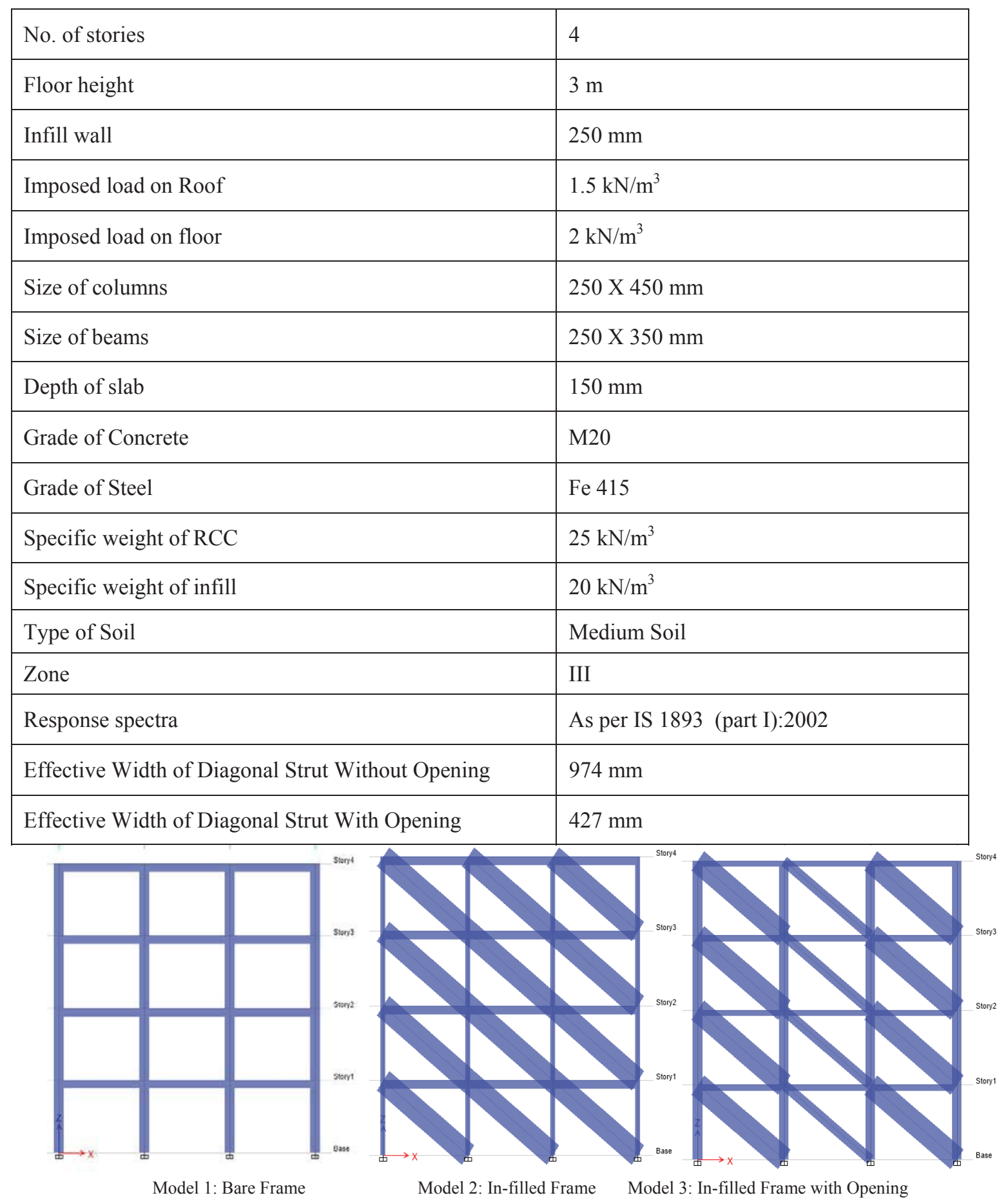




\section{RESULT AND DISCUSSION}

The seismic analysis of all the frame models that includes bare frame, in-filled frame and In-filled frame with opening has been done by using software ETABS and the results are shown below. The parameters which are to be studied are time period, story shear and Displacement.

\subsection{Story Shear}

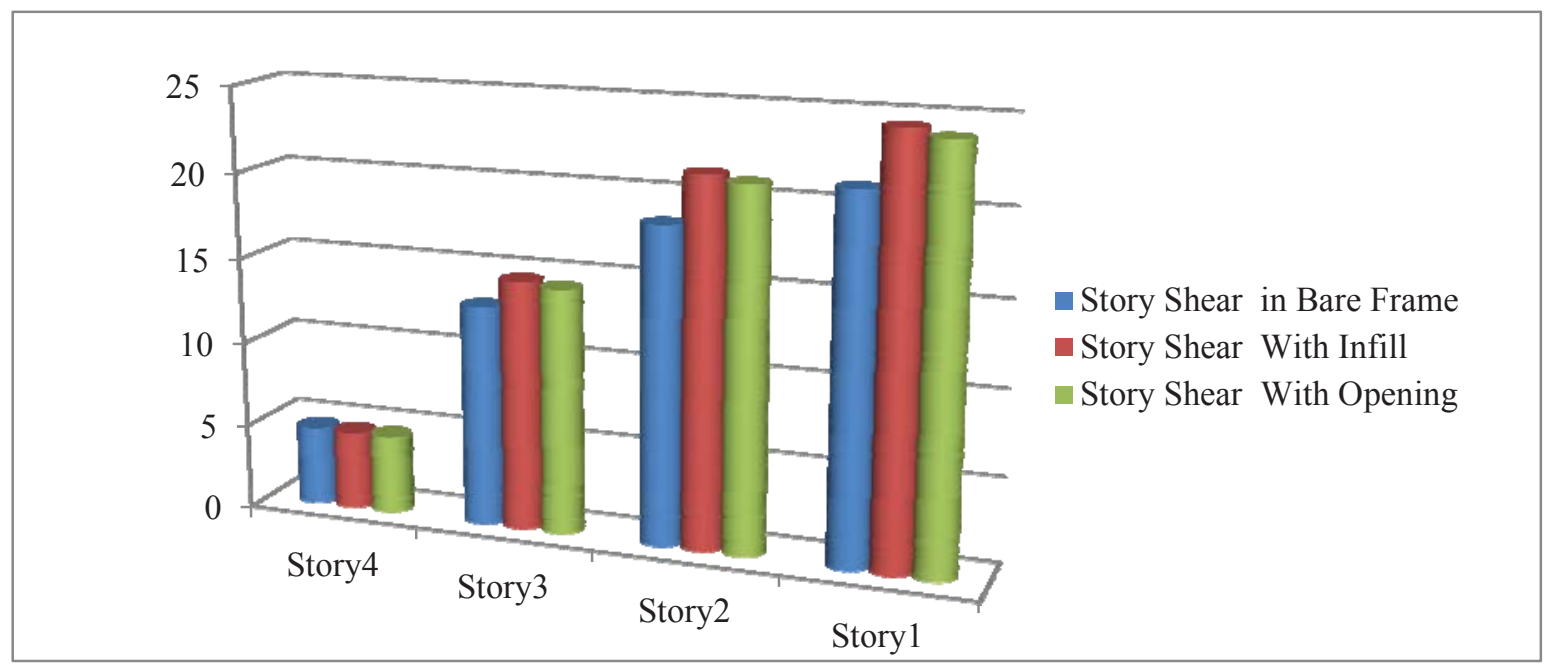

Figure 4.1: Comparison of Story Shear

Above figure 4.1 shows Comparison of story shear. It shows the story shear for bare frame, In-filled frame and infilled frame with openings for all stories. It explains that the Story shear of in-filled frame is more as compared to bare frame and In-filled frame with openings.

\subsection{Displacement}

Figure 4.2 shows Comparison of Displacement. It shows the Displacement for bare frame, In-filled frame and infilled frame with openings for all stories. It explains that the Displacement of in-filled frame is less as compared to bare frame and In-filled frame with openings

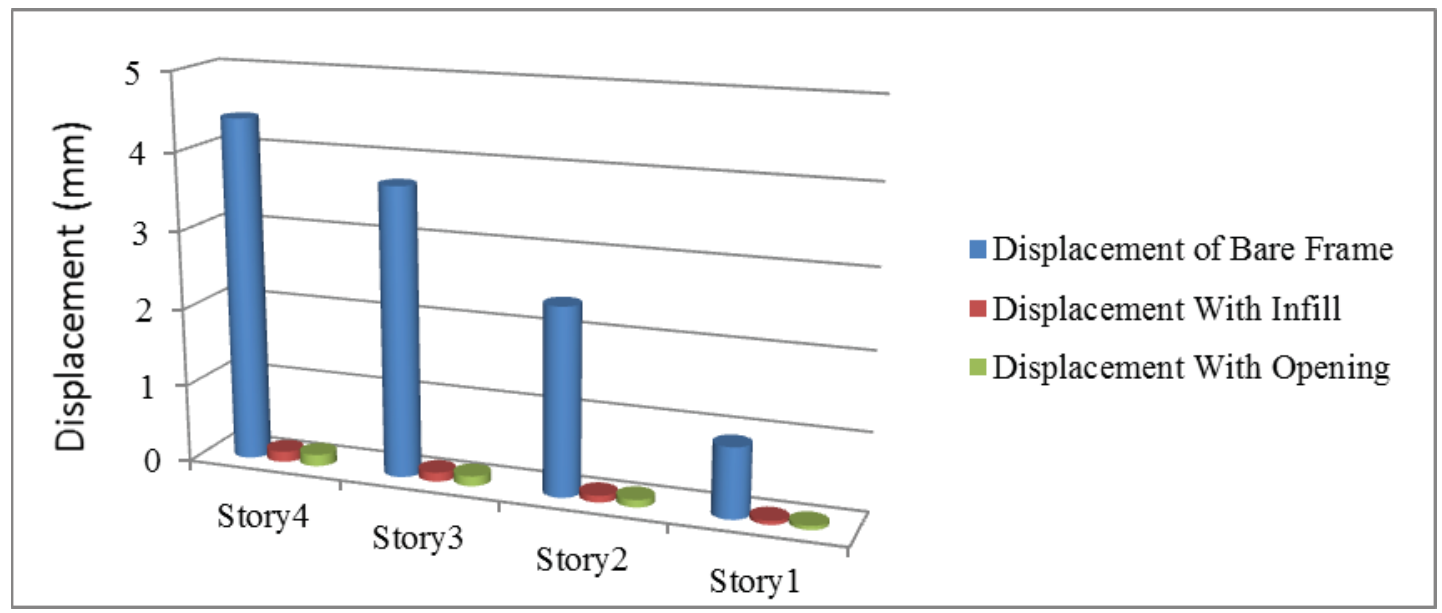

Figure 4.2: Comparison of Displacement

\subsection{Time Period}




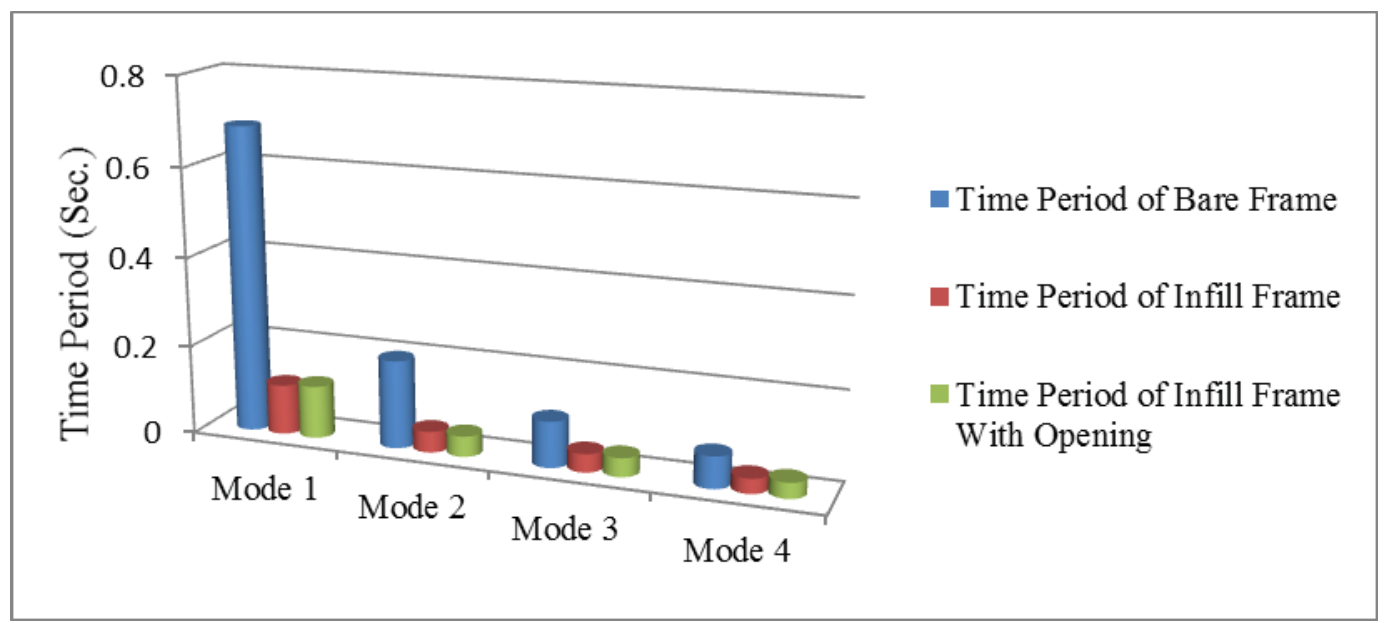

Figure 4.3: Comparison of Time Period

Figure 4.3 shows Comparison of Time Period. It shows the Time Period for bare frame, In-filled frame and in-filled frame with openings for all stories. It explains that the Time Period of in-filled frame is less as compared to bare frame and In-filled frame with openings.

\section{V.CONCLUSION}

Based on above study the following conclusions are drawn,

1. The consideration of masonry infill as equivalent diagonal strut in the elastic response spectrum method of analysis is helpful, in reducing the displacement of the structure and may be used to limit drift of structure.

2. The base shear of infill frame is more than in-filled frame with opening and bare frame.

3. The time Period of in-filled frame is less as compared to in-filled frame with opening and bare frame.

\section{REFERENCES}

[1] Goutam mondal and Sudhir K. Jain, 2008 “ Lateral Stiffness of Masonry Infilled Reinforced Concrete (RC) Frames with Central Opening” Earthquake Spectra, volume 24, No. 3

[2] Jaswant N.Arlekar, Sudhir K.Jain, and C.V.R.Murty, 1997 "Seismic Response of Frame Buildings with Soft First Storeys" Proceedings of the CBRI Golden Jubilee Conference on Natural Hazards in Urban Habitat, New Delhi.

[3] V.K.R.Kodur, M.A.Erki and J.H.P.Quenneville, July 1998 "Seismic analysis of infilled frames" Journal of Structural Engineering Vol.25, No.2, PP 95-102.

[4] Hossain Mohammad Muyeed-Ul-Azam and Khan Mahmud Amanat 2005. "ffect of Infill as a Structural Component on the Column Design of Multi-storied Building”. UAP Journal of Civil and Environmental Engineering Vol. 1, No. 1.

[5] Mehmet Metin Kose, 2009 "Parameters affecting the fundamental period of RC buildings with infill walls" Engineering Structures 31), 93-102.

[6] J. Dorji and D.P. Thambiratnam, 2009. "Modeling and Analysis of Infilled Frame Structures under Seismic Loads". The Open Construction and Building Technology Journal, 3, 119-126

[7] Mulgund G.V. and Dr.Kulkarni A.B. ,2011. "Seismic Assessment of RC Frame Buildings with brick masonry infill.” Mulgund GV Et Al. / (IJAEST) International Journal Of Advanced Engineering Sciences And Technologies Vol. 2, Issue No. 2, 140-147.

[8] P.M.Pradhan, P.L.Pradhan, R.K.Maskey, February 2012 "Kathmandu University Journal of Sciences, Engineering and Technology, Vol.8 No I, Pp 142-152

[9] Haroon Rasheed Tamboli and Umesh.N.Karadi ,2012 "Seismic Analysis of RC Frame Structure with and without Masonry Infill Walls." Indian Journal Of Natural Sciences, Vol.3 / Issue 14.

[10] Wakchaure M.R and Ped S. P, 2012 "Earthquake Analysis of High Rise Building with and Without In filled Walls", International Journal of Engineering and Innovative Technology (IJEIT) Volume 2, Issue 2.

[11] Mohammad H. Jinya and V. R. Patel , 2014 "Analysis of Rc Frame With And Without Masonry Infill Wall With Different Stiffness With Outer Central Opening” International Journal of Research in Engineering and Technology, Volume: 03 Issue: 06. 